\title{
イオン液体の階層的構造およびダイナミクス
}

古府 麻衣子

（東京大学 物性研究所）

\section{Hierarchical Structure and Dynamics in Ionic Liquids}

Maiko Kofu

Institute for Solid State Physics, University of Tokyo

\section{0}

\begin{abstract}
In the past decade, ionic liquids (ILs) have gained increasing attention in many fields, since they possess several unique properties, such as negligible vapor pressure, high ionic conductivity, and wide range of solubility. One of the most interesting features in imidazolium-based ILs is a higher order structure reflecting the nanoscale segregation of polar and nonpolar domains. The structure and dynamics of the ILs were investigated by means of neutron diffraction and quasielastic scattering techniques. It was found that the nanostructure drastically grows upon cooling. Furthermore, we have successfully observed the relaxation of nanostructure, ionic diffusion, imidazolium relaxation, and alkyl reorientation separately. From the anion/cation dependence of the relaxation processes, it is concluded that the hierarchical dynamics in the ILs is predominantly governed by the Coulombic interaction between the polar parts of cations and anions.

Keywords: ionic liquid, quasielastic neutron scattering, nanostructure
\end{abstract}

1.はじめに

近年，「イオン液体」とよばれる多機能液体が注 目を集めている。イオン液体は水や通常の有機液 体と異なり，イオンのみからなる新しい液体であ る. 単一のイオン性物質であるにもかかわらず, 室温付近で液体状態をとるのは特異である（例え ば $\mathrm{NaCl}$ の融点は約 $\left.800^{\circ} \mathrm{C}\right)$ ．多くのイオン液体の 陽イオンは，正電荷を有するコア部分（イミダゾ リウム環やピリジニウム環）に疎水的なアルキル 鎖が結合した構造をもつ（Fig. 1)。一方，陰イオ ンは八ロゲンイオン $\left(\mathrm{Cl}^{-}, \mathrm{Br}^{-}, \mathrm{I}^{-}\right)$や様々な多原子 イオン $\left(\mathrm{NO}_{3}{ }^{-}, \mathrm{BF}_{4}^{-}, \mathrm{PF}_{6}^{-},\left[\mathrm{CF}_{3} \mathrm{SO}_{2}\right]_{2} \mathrm{~N}^{-}\right.$など $)$が成 りうる.イオン液体の多くは両親媒性を有し, 様々 な有用な特性を示寸. 例えば, 低蒸気圧, 難燃性, 難分解性などの熱力学的安定性, 高イオン伝導性, 広電位空などの電気化学特性，広範囲の物質の可 溶性などである。これらの特性は，陰陽両イオン を変えることにより制御可能であり，イオン液体 はデザイナー溶媒とも呼ばれている.

イミダゾリウム系イオン液体の一番の特徴は,
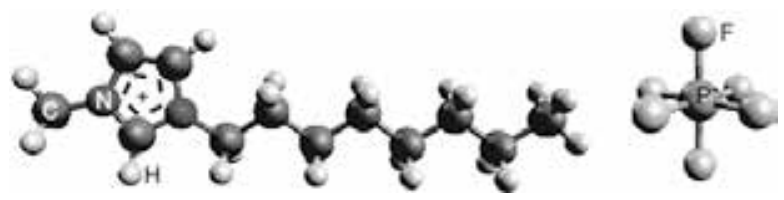

Fig. 1. Molecular structure of $\mathrm{C} \mathrm{mimPF}_{6}$.
その階層的な構造である。陽イオンのアルキル鎖 からなる非極性ドメインと，陽イオンの極性部分 および陰イオンからなる極性ドメインが高次構造

（ナノ構造）を形成する[1-4]. 各々のドメイン内 にも特徵的な構造が存在するので，イオン液体は 階層構造を有する液体とも捉えることができる.

水・油・界面活性剂系などで階層構造が見られる ことはしばしばあるが，単一成分の液体でこのよ うな構造が現れることは非常に興味深い。

通常の液体の概念を破るような多様でユニーク なイオン液体を理解するため, 我々は中性子散乱 法や他の手法を用いてイオン液体および関連物質 の研究を行ってきた[5-10]. 本稿では, イミダゾリ ウム系イオン液体の階層構造とそれに起因寸る 種々のダイナミクスについて紹介寸る，紙面の都 合上, 全ての結果を示すことはできないが, 我々 が行ってきたイオン液体研究について概観して頂 ければ幸いである.

\section{2. 中性子散乱実験}

まず非干渉性・干渉性準弾性散乱について簡単 に述べておく. 軽水素の非干渉性散乱断面積は 80 barn と他の原子の散乱断面積（数 barn 程度）より も圧倒的に大きい. 従って, 軽水素を含む試料を 測定すると，軽水素（およびそれと強く結合した 原子や原子団）の単独運動（自己拡散）を観測す ることができる，一方，軽水素を重水素に置き換 
(a)

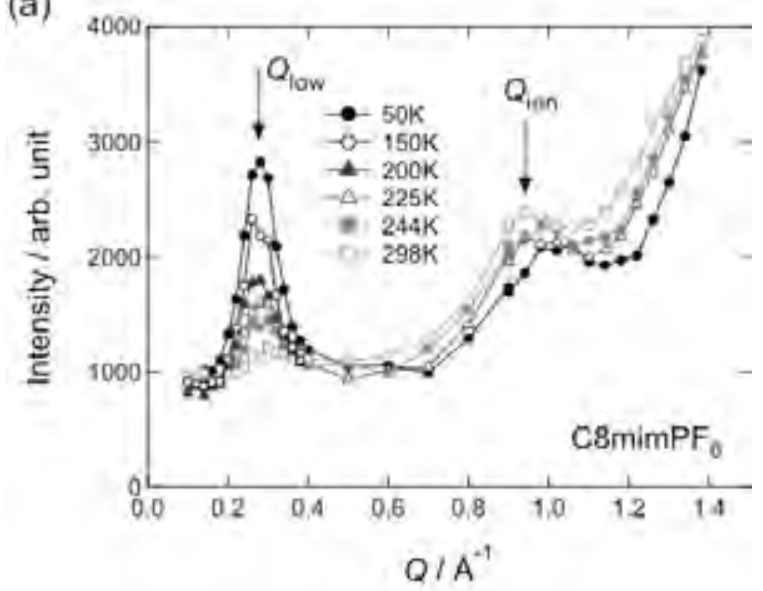

(b)

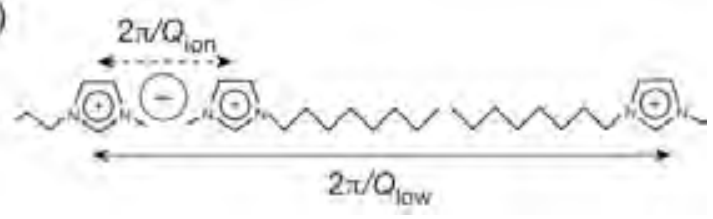

Fig. 2. (a) Temperature dependence of neutron diffraction patterns of d-C $8 \mathrm{mimPF}_{6}$. (b) Schematic drawing of the correlations between the imidazolium rings.

え，干渉性散乱の寄与を大きくすると，特定の距 離相関の運動を観測することができる.

本研究では, イオン液体の階層構造・ダイナミ クスを調べるために中性子回折および準弾性散乱 測定を行った。試料は, 最も広く研究されている アルキルイミダゾリウム系イオン液体 (CnmimX : $n$ はアルキル鎖の炭素数，X は陰イオン）を選択 した。重水素試料を用いた中性子回折および干涉 性準弹性散乱測定は, 米国標準技術研究所 (NIST) に設置された中性子スピンエコー装置 NSE を用 いて行った。 中性子スピンエコー法では，得られ るデータは $S(Q, \omega)$ ではなくその時間フーリエ変換 に対応する中間散乱関数 $I(Q, t)$ であるため, 緩和測 定に非常に適している。.また，中性子分光装置の なかでも最もエネルギー分解能が高く, 遅い緩和 を調べることができる。

軽水素試料を用いた非干渉性準弾性散乱測定に は, 日本原子力研究開発機構の JRR-3 原子炉に設 置された東大物性研の高分解能パルス冷中性子分 光器 AGNES および NIST に設置された後方散乱 装置 HFBS の 2 つを用いた．2つの装置を用いた のは，広い時間領域をカバーするためである。非 干渉性準弾性散乱測定では, 運動を $Q$ によって分 離するのではなく, 緩和時間によって分離する. また，緩和時間や緩和強度の $Q$ 依存性を調べるこ とにより，運動の空間情報を得ることができる.

NSE と異なり, AGNES や HFBS では同時に複数 の $Q$ 位置で準弾性散乱を測定することができ，非 干渉性散乱測定に適している。また， $\mathrm{H}$ 原子から の散乱が大きいため，短時間でデータを取得可能 である. 本研究では運動のアルキル鎖長・陰イオ ン種依存性を調べるため, 合計 10 試料を測定した.

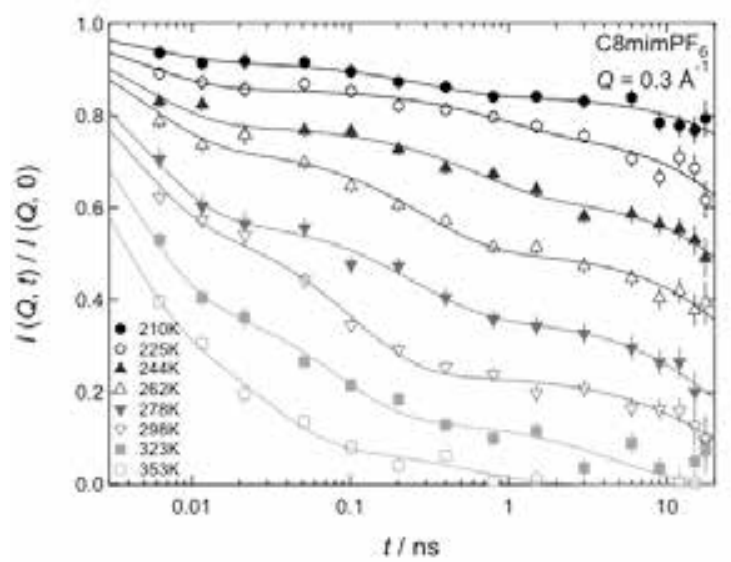

Fig. 3. Intermediate scattering functions of d-C $8 \mathrm{mimPF}_{6}$ taken at $Q=0.3 \AA^{-1}$.

\section{3. イオン液体のナノ構造}

$\mathrm{NSE}$ 分光器で測定した重水素化 $\mathrm{C} 8 \mathrm{mimPF}_{6}$ $\left(\mathrm{d}-\mathrm{C} 8 \mathrm{mimPF}_{6}\right)$ の中性子回折パターンの温度変化 を Fig. 2(a)に示す. $Q=1.0 \AA^{-1}\left(=Q_{\text {ion }}\right)$ 付近のピ 一クは隣り合ったイミダゾリウム環あるいは陰イ オン同士の 2 体相関（イオン相関）に対応寸る. このピークは陰イオンが大きいほど低 $Q$ にシフト する. 一方, $Q=0.3 \AA^{-1}\left(=Q_{\mathrm{low}}\right)$ 付近のピークは アルキル鎖によって隔てられたイミダゾリウム環 間距離に対応する（Fig. 2(b)参照）。距離 $2 \pi / Q_{\text {low }}$ は大まかにアルキル鎖 2 本分にイオン部分の大き さを足したものとなっており，少なくとも室温付 近の液体状態では，アルキル鎖はあまり相互貫入 していない. 結晶ではアルキル鎖は相互貫入して おり，液体の構造との違いの一つである. 冷却す ると, イオン相関ピーク位置 $\left(Q_{\mathrm{ion}}\right)$ は高 $Q$ 側に 少しシフト寸る. これは, 密度の増大 (イオンの パッキングが良くなること）によるものである. 興味深いのは, 低 $Q$ ピークの温度変化である. 冷 却に伴い，ピーク強度が劇的に増大寸る。これは ナノ構造が低温で急激に成長していることを示唆 する. 低 $Q$ ピークの起源については現在も議論が あるが, 長いアルキル鎖長をもつ $\mathrm{C} n \operatorname{mimX}(n>12)$ では液晶相（smectic A：SmA）が発現すること， また $\mathrm{SmA}$ 相の層間距離に対応するブラッグピー クと低 $Q$ ピークがほぼ同位置に現れること[11]か ら，イオン液体のナノ構造は液晶相の層構造のゆ らぎであると我々は考えている.

\section{4. イオン液体の微視的ダイナミクス}

4.1. 干涉性準弾性散乱

ナノ構造およびイオン相関のダイナミクスを調 ベるために，中性子スピンエコー測定を行った. イオン相関のダイナミクスについては, 後述する 非干渉性準弾性散乱でも測定しているので，ここ では割愛する. Fig. 3 は $Q=Q_{\text {low }}$ での d-C $8 \mathrm{mimPF}_{6}$ の中間散乱関数 $I(Q, t) / I(Q, 0)$ である. このデータは 
$\frac{I(Q, t)}{I(Q, 0)}=f_{1} \exp \left(-t / \tau_{1}\right)+f_{2} \exp \left(-t / \tau_{2}\right)+f_{3} \exp \left(-t / \tau_{3}\right)$

という 3 つの指数関数 $\left(\tau_{1}<\tau_{2}<\tau_{3}\right)$ の和でフィッ トした。ここで $f_{1}+f_{2}+f_{3}=1$ である.温度低下に 伴い, 速い緩和の分率 $f_{1}+f_{2}$ は減少し, 一方遅い 緩和の分率 $f_{3}$ は増大寸る. $f_{3}$ の温度変化は低 $Q$ ピ 一クの強度変化とほぼ対応する。このことから， 速い緩和（ $\left.\tau_{1} ， \tau_{2}\right)$ と遅い緩和 $\left(\tau_{3}\right)$ は，それぞれ ナノ構造が壊れた部分の緩和とナノ構造の緩和で あると推測される。イオン液体におけるナノ構造 の緩和が観測されたのは，この実験が初めてであ る。イオン液体にはナノ構造が秩序化した領域と 無秩序な領域が混在しており，昇温によりナノ構 造はぼやけ，無秩序領域は増大する。室温付近の イオン液体は非常に不均一な状態にあり，ナノ構 造の起源について決着を付けるためには低温での より精密な実験・シミュレーションが必要であろ う.

\section{2. 非干渉性準弾性散乱}

ナノ構造緩和より速い緩和を詳細に調べるため, 非干渉性準弾性散乱測定を行った。陰イオンやア ルキル鎖長を変化した際に，微視的ダイナミクス がどのように変化するか調べるため，アルキル鎖 長・陰イオン種を変え測定を行った。 AGNES と HFBS ではエネルギー分解能・エネルギー領域が

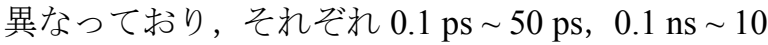
ns の時間領域の緩和挙動を調べることができる. 測定には軽水素試料を用いており，H 原子を含む 陽イオンの自己拡散を主に観測していることにな る.

まず, C8mimTFSI（TFSI : $\left[\mathrm{CF}_{3} \mathrm{SO}_{2}\right]_{2} \mathrm{~N}$ ）につい てAGNES と HFBS で得られた準弾性散乱スペク トルを Fig. 4 に示す. 両装置で， $\hbar \omega=0$ を中心に ブロードなピーク（準弾性散乱）が観測された.

AGNES のデータは以下のような $\delta$ 関数 (弾性成分)

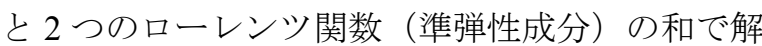
析した.

$$
\begin{aligned}
& S(Q, \omega)=R(Q, \omega) \otimes\left\{A_{\mathrm{E}} \delta(\omega)+\sum_{i=1}^{2} A_{i} L_{i}(\omega)\right\}+\mathrm{BG} \\
& L_{i}(\omega)=\frac{1}{\pi} \frac{\Delta \omega_{i}}{\omega^{2}+\Delta \omega_{i}^{2}}
\end{aligned}
$$

ここで， $R(Q, \omega)$ は分解能関数， $\otimes$ は畳み込み演算 子， $\mathrm{BG}$ はバックグラウンドである. 図中のカー ブは，それぞれの関数の分率 $\left(A_{\mathrm{E}}, A_{i}\right)$ と半值半幅 $\Delta \omega_{i}$ および $\mathrm{BG}$ を可変パラメータにしてフィッテ イングした結果である.Fig. 4 には，各関数の寄 与も合わせて示してある。ローレンツ関数は指数 関数 $\exp (-t / \tau)$ のフーリエ変換であり，緩和時間 $\tau$ は $\tau=1 / \Delta \omega か ら$ 見積もることができる．一方，HFBS で得られた準弾性スペクトルは伸長指数関数のフ 一リ工変換
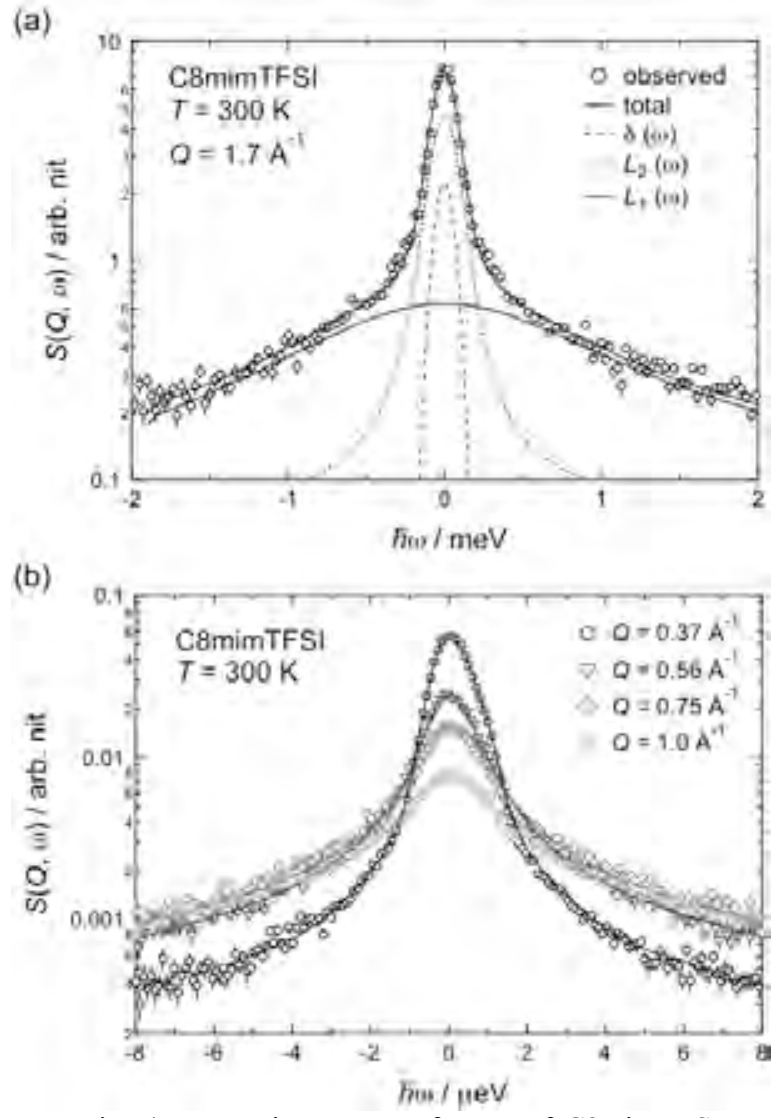

Fig. 4. Dynamic structure factors of C8mimTFSI taken on (a) AGNES and (b) HFBS.

$$
S(Q, \omega)=R(Q, \omega) \otimes F T\left[B \exp \left\{-\left(t / \tau_{3}\right)^{\beta}\right\}\right]+\mathrm{BG}
$$

でよくフィットできた。この緩和は AGNES では 弾性散乱として観測された成分である。つまり， AGNES の時間領域（0.1 ps～50 ps）では “静止し ている”ように見えたものが，HFBS の時間領域 (0.1 ns 〜 $10 \mathrm{ns)}$ では “動いている”ものとして 検知できたことになる.ここで, 指数 $\beta(0<\beta \leq 1)$ は非指数性パラメータと呼ばれ, 緩和時間の分布 の度合いを表している $(\beta=1$ では単一の緩和時間 をもつ). また，平均緩和時間 $\langle\tau>$ は $\langle\tau\rangle=\tau / \beta$ ・ $\Gamma(1 / \beta)$ から見積もられる.ここでГはガンマ関数で ある.フィッティングから見積もられた $\beta$ はおお よそ0.5であった。

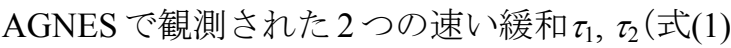
の $\tau_{1}, \tau_{2}$ と異なることに注意) はほぼ $Q$ に依存せず, 局所運動であることがわかった。一番速い緩和 $\left(\tau_{1}\right)$ の緩和強度の分率は 0.8 程度で, これは陽イオン に含まれる $\mathrm{H}$ 原子 (23 個) のうちアルキル鎖とメ チル基中の $\mathrm{H}$ 原子の数（20 個）の割合にほぼ対応 する．従って，この緩和はアルキル鎖の局所回転 運動であると結論付けられる。一方, 次に速い緩 和 $\left(\tau_{2}\right)$ の緩和強度は残りの $\mathrm{H}$ 原子からの寄与で あり，この緩和はイミダゾリウム環の運動と考え られる.緩和強度の分率の $Q$ 依存性を解析すると, $\mathrm{H}$ 原子は半径 $1.7 \AA$ 程度の空間を動いていること 

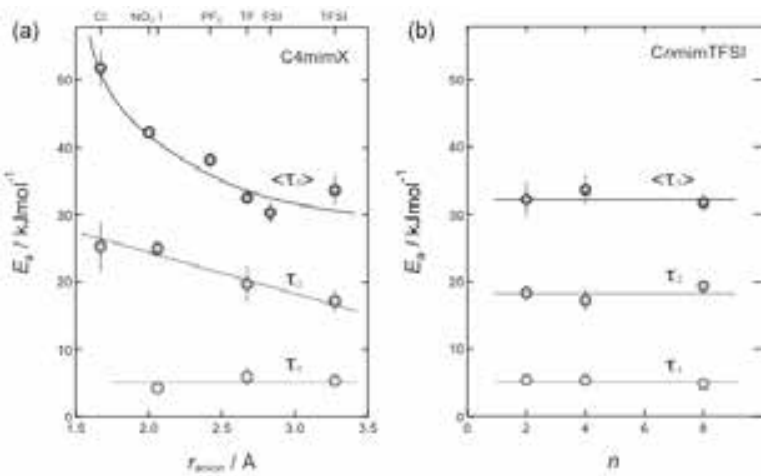

Fig. 5. Activation energies against (a) anion radius and (b) alkyl carbon number.

がわかつた。この值はイミダゾリウム環の半径 (2.25 ̊) よりも小さく，この運動はイミダゾリ ウム環の全体回転ではなく科動運動のような小規 模の運動（局所運動）であると考えられる.

一方, HFBS で観測した遅い緩和 $<\tau_{3}>$ は $Q_{2}$ に依 存し, ジャンプ拡散モデル $<\tau>^{-1}=D Q^{2} /\left(1+D Q^{2} \tau_{\mathrm{r}}\right)$ で 大まかに記述できた。ジャンプ拡散モデルとは， 粒子（分子）がある位置に時間 $\tau_{\mathrm{r}}$ 帯在した後，別 の位置にジャンプするというモデルであり，液体 の並進拡散運動はこのモデルに従うことが多い

(ここで $D$ は拡散係数)。従って，この緩和は陽 イオンの並進拡散（イオン拡散）であると考えら れる。

Fig. 5 に 3 つの緩和の活性化エネルギー $E_{\mathrm{a}}$ の陰 イオンおよびアルキル鎖長に対する依存性を示す. $E_{\mathrm{a}}$ はアレニウス式 $\tau=\tau_{0} \exp \left(E_{\mathrm{a}} / R T\right)$ から求めた。一 番速い緩和 $\left(\tau_{1}\right)$ の $E_{\mathrm{a}}$ は陰イオン種に依らないが, 遅い 2 つの緩和 $\left(\tau_{2},<\tau_{3}>\right)$ の $E_{\mathrm{a}}$ は陰イオンを大き くすると減少する。このことは，これら 2 つの緩 和が，陰イオンとイミダゾリウム環の間に働くク 一ロン相互作用によって支配されていることを示 している。一方，どの緩和もアルキル鎖長を変え てもほとんど変わらない（Fig. 5(b))。これはイオ ン液体のナノ構造を考えると理解できる。冒頭で 述べたように，イオン液体では極性部分と無極性 部分はそれぞれ集合し，ミクロ相分離している

(Fig. 6 参照)。陰イオンを変えると，クーロン相 互作用の大きさが変化するため, イオン拡散 $\left(<\tau_{3}>\right)$ とイミダゾリウム環の運動（ $\tau_{2} ）$ は影響を受ける が，別の領域にあるアルキル鎖の回転運動 $\left(\tau_{1}\right)$ は鈍感である.同様に, アルキル鎖の回転運動 $\left(\tau_{1}\right)$ は陰イオンを変えても影響をあまり受けない。ま た，アルキル鎖長にも依らない。これは，アルキ ル鎖の運動が局所運動であり，周囲の $\mathrm{CH}_{2}$ 基が作 るポテンシャルによって支配されるためである.

\section{3. 階層的ダイナミクスの全体像}

中性子準弾性散乱により観測された緩和の温度 依存性の全体像（緩和マップ）をFig. 6 に示す. 4 つの運動の模式図も合わせて示した. 室温付近で, アルキル鎖は $1 \mathrm{ps}$ 程度の時間スケールで動いてお り，あまり温度依存しない $\left(E_{\mathrm{a}} \sim 5 \mathrm{~kJ} / \mathrm{mol}\right)$ ．イミ
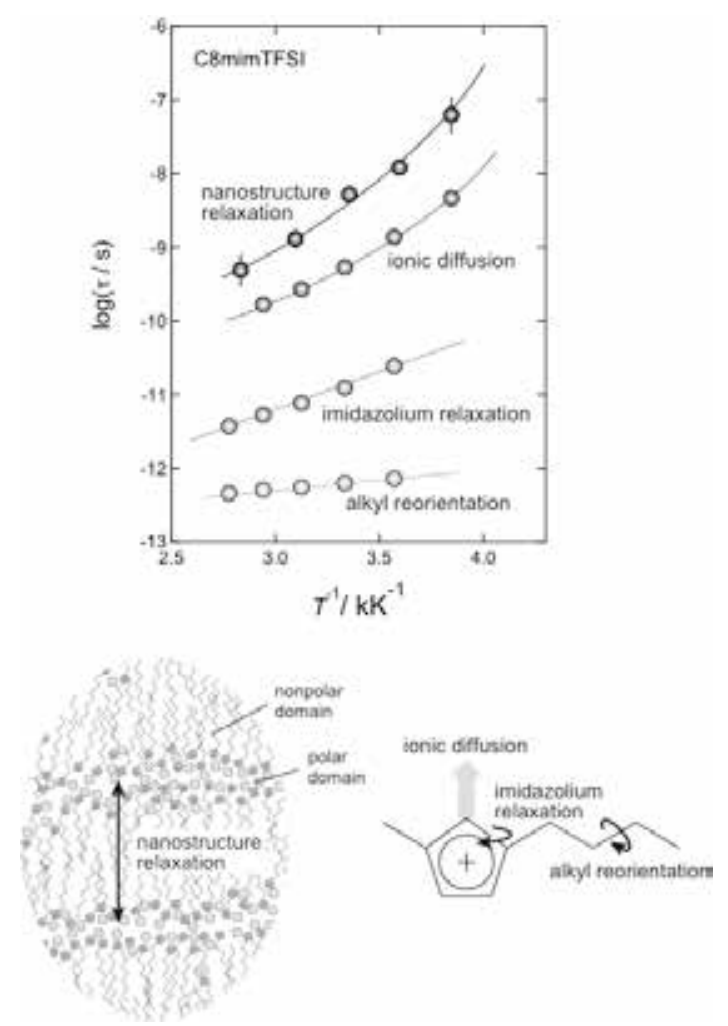

Fig. 6. Overall relaxation map of C8mimTFSI obtained by quasielastic neutron scattering and schematic drawing of each relaxation.

ダゾリウム環の局所緩和は $1 \sim 10 \mathrm{ps}$ 領域で起こり， その活性化エネルギーは $E_{\mathrm{a}}=15 \sim 25 \mathrm{~kJ} / \mathrm{mol}$ であ る.イオン拡散は $0.1 \sim 10 \mathrm{~ns}$ の時間領域にあり, 活性化エネルギーは陰イオン種によって大きく異 なる $\left(E_{\mathrm{a}}=30 \sim 50 \mathrm{~kJ} / \mathrm{mol}\right)$. 興味深いことに，ナノ 構造緩和の活性化エネルギーはイオン拡散のもの とあまり変わらず，陰イオン依存性も類似してい る.つまり，ナノ構造のエネルギ一的安定性を主 に支配しているのはイオン部分のクーロン相互作 用である. イオン液体の層構造はそれほど強固な ものではなく，ナノ構造とその壊れた構造の自由 エネルギーに大きな差はないことを示唆している。 最後に，ガラス特性との関係について触れてお く. 我々は, 低温の粘弾性測定も行い, イオン拡 散 $\left(<\tau_{3}>\right)$ との比較を行った. $T=1.4 T_{\mathrm{g}}\left(T_{\mathrm{g}}\right.$ : ガラ 又転移温度）付近で $<\tau_{3}>$ と粘度の温度依存性はほ ぼ同じであり，また測定した全試料で $<\tau_{3}>$ と粘度 の比例関係（ストークス・アインシュタイン性） が確認できた。この結果は，アルキル鎖の運動で はなく, イオン拡散が粘度およびガラス転移と直 接関係していることを示唆している．実際，ガラ ス転移温度やイオン拡散の活性化エネルギーはク 一ロン相互作用により決定されているように思え る.

それでは，アルキル鎖の役割とは何であろう か? イオン液体が低融点である理由として, (i) イ オンがアルキル鎖により隔てられ，結晶でのクー ロン相互作用が弱くなること，(ii) 液体状態でア ルキル鎖が非常に高い自由度をもつことによりエ 
ントロピー的に安定化すること, (iii) 液体状態が ミクロ相分離構造（ナノ構造）の形成によりエン タルピー的に安定化すること，などが考えられる. アルキル鎖の存在は，イオン液体のダイナミクスよ りも, “イオン液体”という状態の実現（熱力学的 安定性）に重要な役割を果たしているようである.

\section{5. おわりに}

7 年前, 山室研究室の助教として着任するまで, 私は超伝導や量子スピン系などの研究を行ってい ました。当時の私は，液体研究や準弾性散乱につ いて何も知らず，まず勉強することから始めまし た. 7 年間こつこつと進めたイオン液体の研究が 評価され，日本中性子科学会奨励賞を受賞するに 至ったことを非常に嬉しく感じています.

さまざまな物質系の研究を行ううえで，いろい ろな中性子散乱装置や手法に触れてきました. そ の都度，それまで自分が知らなかったことに出会 い，小さな発見に心躍ることもありました．もち ろん既に誰かが知っていることも多かったのです が，何かを分かるということは嬉しいものです。 このような経験は私の財産になっていると思いま す. 最初に中性子散乱実験を行ったのは 15 年前に なります.この 15 年間, 中性子散乱に関われたこ とを嬉しく思います。私を中性子散乱の道に導い てくれた故廣田和馬先生に感謝の誠を捧げます。

\section{謝辞}

このイオン液体の研究は, 多くの方々の協力な しには成し得ませんでした，研究を一緒に進めて いただいた山室修教授, 稲村泰弘博士 (現 J-PARC センター), 議論に付き合っていただいた山室研究 室のメンバー，中性子散乱実験をサポートしてい ただいた NIST 長尾道弘博士, Madhusudan Tyagi 博士，重水素試料を合成してくださった横国大の 上木岳士博士 (現物材機構), 北沢侑造博士, 渡邊 正義教授に心より感謝申し上げます。.また，ご推 薦いただいた方々，選考委員会の皆様はじめ学会 関係者の皆様に御礼申し上げます.

\section{参考文献}

[1] J. N. C. Lopes, N. F. Costa Gomes, and A. A. H. Pádua, J. Phys. Chem. B 110, 16816 (2006).

[2] A. Triolo, O. Russina, H.-J. Bleif, and E. Di Cola, J. Phys. Chem. B 111, 4641 (2007).

[3] A. Triolo, O. Russina, B. Fazio, R. Triolo, and E. Di Cola, Chem. Phys. Lett. 457, 362 (2008).

[4] H. V. R. Annapureddy, H. K. Kashyap, P. M. De Biase, and C. J. Margulis, J. Phys. Chem. B 114, 16838 (2010).

[5] O. Yamamuro, T. Yamada, M. Kofu, M. Nakakoshi, and M. Nagao, J. Chem. Phys. 135, 054508 (2011).

[6] M. Kofu, T. Someya, S. Tatsumi, K. Ueno, T. Ueki, M. Watanabe, T. Matsunaga, M. Shibayama, V. Garcia Sakai, M. Tyagi, and O. Yamamuro, Soft Matter 8, 7888 (2012).
[7] M. Kofu, M. Nagao, T. Ueki, Y. Kitazawa, Y. Nakamura, S. Sawamura, M. Watanabe, and O. Yamamuro, J. Phys. Chem. B 117, 2773 (2013).

[8] 古府麻衣子，山室修，波紋 24, 126 (2014).

[9] M. Kofu, Y. Inamura, Y. Moriya, A. Podlesnyak, G. Ehlers, and O. Yamamuro, J. Mol. Liq. 210, 164 (2015).

[10] M. Kofu, M. Tyagi, Y. Inamura, K. Miyazaki, and O. Yamamuro, J. Chem. Phys. 143, 234502 (2015).

[11] F. Nemoto, M. Kofu, and O. Yamamuro, J. Phys. Chem. B 119, 5028 (2015). 